\title{
SOCIAL AND ECONOMIC EFFICIENCY OF IMPLEMENTATION OF PASTILE PRODUCTS MADE FROM UNCONVENTIONAL RAW MATERIALS IN THE HOSPITALITY FIELD
}

\author{
Olena Sokolovska', Anna Radchenko ${ }^{2}$, Yana Biletska ${ }^{3}$, Anna Krivtsova ${ }^{4}$, Anastasia Kornitskaya, \\ Tetyana Afanasieva ${ }^{6}$, Olha Bilovska \\ ${ }^{1}$ Department of International Ecommerce and Hotel and Restaurant Business, V. N. Karazin Kharkiv National University, Kharkiv, Ukraine \\ olenasokolovska@karazin.ua \\ ORCID: https://orcid.org/0000-0002-6422-8915 \\ ${ }^{2}$ Department of Food Technology in Restaurant Industry, Kharkiv State University of Food Technology and Trade, Kharkiv, Ukraine \\ gasanova.anna.edyardovna@gmail.com \\ ORCID: https://orcid.org/0000-0002-7101-6208 \\ ${ }^{3}$ Department of International Ecommerce and Hotel and Restaurant Business, V. N. Karazin Kharkiv National University, Kharkiv, Ukraine \\ monika3384@ukr.net \\ ORCID: https://orcid.org/0000-0001-8060-6579 \\ ${ }^{4}$ Department of International Ecommerce and Hotel and Restaurant Business, V. N. Karazin Kharkiv National University, Kharkiv, Ukraine \\ anna.perepelytsia@karazin.ua \\ ORCID: https://orcid.org/0000-0003-0647-2941 \\ ${ }^{5}$ Department of Food Technology, Hotel and Restaurant Business, Kharkiv College of Trade and Economics, Kyiv National University of \\ Trade and Economics, Kharkiv, Ukraine \\ nnnastja23@ukr.net \\ ORCID: https://orcid.org/0000-0002-5689-1039 \\ ${ }^{6}$ Department Food Technologies and Restaurant Business, Kharkiv College of Trade and Economics, Kyiv National University of Trade \\ and Economics, Kharkiv, Ukraine \\ ORCID: https://orcid.org/0000-0001-6809-3627 \\ ${ }^{7}$ Department of International Ecommerce and Hotel and Restaurant Business, V. N. Karazin Kharkiv National University, Kharkiv, Ukraine \\ o.bilovska@karazin.ua \\ ORCID: https://orcid.org/0000-0002-2808-5275
}

ARTICLE INFO

Article history:

Received date 25.03.2021

Accepted date 26.04.2021

Published date 30.04.2021

Section:

Food Science

D O I

$10.21303 / 2313-8416.2021 .001808$

KEYWORDS

pastilles

elamin

stevia

marshmallows

pastille

sweetener

iodine-containing raw materials

economic and social efficiency

\section{ABSTRACT}

In the context of the deteriorating environmental situation, scientists are faced with the urgent task of improving the quality of food. One way is to reduce the carbohydrate load by replacing sugar in sweeteners while enriching them with nutrients. One way is to reduce the carbohydrate load by replacing sugar in sweeteners while enriching them with nutrients. For this purpose, a number of studies have been carried out to improve the quality of pastilles through the use of stevia - a natural sweetener and elamin

The objects of research are social and economic efficiency.

Investigated problem was to calculate the social and economic efficiency from the introduction of the developed marshmallow.

Main scientific results: The article presents these calculations of the economic efficiency of the implementation of the development, namely, a decrease in the realizable value of the Exotica pastille by $1.2 \%$ and an increase in the "Smakota" pastille and "Nasoloda" marshmallow by 4.0 and $2.3 \%$. However, it was found that the integral quality indicator of marshmallow "Nasoloda" exceeds the control by $10.2 \%$, for the pastille "Exotica" and "Smakota" - by 21.1 and $26.3 \%$.

Scope of practical use of the development is the food industry, namely, the expansion of the range of products with a low glycemic index, increased nutritional value.

An innovative technological product is the technology of making pastilles, which has economic and social efficiency.

Scope of application of the innovative technological product: The use of the developed pastille products for consumers with a lack of iodine, selenium, iron, obesity patients and diabetes mellitus.

(C) The Author(s) 2021. This is an open access article under the Creative Commons CC BY license

\section{Introduction}

Economic efficiency is reflected in the excess of profits from the production and sale of products on the expenses incurred in value terms. The social result of research can be considered the expansion of the assortment of pastilles, which have an increase in quality characteristics and 
are available according to the pricing policy, which in turn is a factor in the formation of proceeds from sales and profit.

\section{1. The object of research}

The objects of research are the economic and social efficiency of the implementation of the developed pastilles.

\section{2. Problem description}

With the deteriorating environmental situation and physical activity, the nutritional structure of the Ukrainian population does not meet modern nutritional requirements, which is associated with an excess of simple sugars and a high glycemic index (GI) of products. The scientific interest of this study lies in the improvement of the recipe composition of pastilles by introducing an aqueous extract of stevia, stevioside and elamin, which makes it possible to obtain products of improved quality and expand their range [1-3]. However, the implementation of this technique requires substantiation of the feasibility of implementing the results by determining the effectiveness of implementation.

Ukrainian scientists are devoted to a number of studies on the development of new types of bakery products with a balanced chemical composition, in particular, enrichment with iodine due to various carriers [4], developed ways of using molded flour products with iodine-containing additives in culinary technologies [5], received a number of patents for the development technologies of biscuit semi-finished products using sugar substitutes [6]. The expediency of the approach to the use of sweeteners and fortification of products with iodine is described in the scientific works of a number of researchers [7-10]. However, the relevance of this issue is obvious, since scientific data on the effect of stevia and elamin, both separately and together, on the consumer properties of pastilles are absent, and there are no data on the effectiveness of such implementation.

\section{3. Suggested solution to the problem}

Taking into account the problems of the present formation of the quality of pastilles with the use of stevia and elamin, it will be possible to obtain products of guaranteed quality that can be used for the prevention of diabetes mellitus and iodine deficiency, which is a timely task. However, at the initial stage of the product life cycle, it is necessary to conduct a number of studies on the feasibility of such an innovation in terms of economic and social efficiency.

The aim of research is to calculate the social and economic efficiency from the introduction of pastilles in the hospitality industry.

\section{Materials and methods}

The economic efficiency of the developed pastilles is calculated using the generally accepted methodology - a mathematical model for calculating the economic efficiency and significance.

\section{Results}

At the initial stage of the formation of the pricing policy, the sales price of the developed products was calculated in comparison with the analogs taken for control, which are manufactured according to the classical recipe and, in terms of composition and purpose, satisfy the needs of the consumer market. The beginning of the formation of the selling price is the cost of production and sale, which are characterized by the cost indicator. The composition of the cost is determined by the Regulation (standard) of accounting 16 "Expenses".

Determination of the cost consists in calculating the cost of raw materials and materials. Expenses under the item "Raw materials and materials" are determined by direct calculation in several stages, taking into account the corresponding formulations and stages of the technological process. Calculations are made for $100 \mathrm{~kg}$ of product or a specific component, before designing a production line. At the first stage, the cost of an aqueous stevia extract (ASE) was calculated (Table 1).

At the second stage, the cost of the syrup, which is used for the manufacture of pastilles with stevia and elamin, is calculated in comparison with the products taken for control. It is determined that the cost of syrup for the manufacture of pastilles according to the developed recipe is lower than for products taken for control, achieved as a result of a decrease in the mass fraction of white sugar. 
Table 1

Calculation of the ASE cost

\begin{tabular}{cccc}
\hline Raw material & Quantity & Price 1 item, c.u. & Cost, c.u. \\
\hline Water, 1 & 20 & 0.0003 & 0.006 \\
Stevia leaves, kg & 0.2 & 10.0 & 2.0 \\
Total: & - & - & 2.006 \\
Cost of 1 1 & - & - & 0.002
\end{tabular}

Note: cost has not been adjusted to match today's price level

At the third stage, calculations of the cost of "Raw materials and materials" of finished pastilles are carried out. The cost of raw materials for the manufacture of pastille with stevia and elamin is higher compared to products made according to traditional recipes. Costs for raw materials for the production of "Exotica" pastille are defined as low, and the "Nasoloda" marshmallow is high. The cost of "Raw materials and materials" is the most significant component of the cost of production, the share of which is about $60.0-70.0 \%$ of the total.

Due to the lack of clear information about the elements of costs, namely, wages; fuel and electricity for industrial needs; depreciation charges; expenses for the maintenance and operation of fixed assets and rental of premises; general production; general business and non-production the calculations were made according to increased standards based on the data of products made according to the classical recipe. As a result, different dynamics of fixed and variable costs are obtained in accordance with the ratio to the volume of processed raw materials. Adjusted other costs as well, taking into account their relevance. In this case, the relevant are the costs of "Raw materials and materials", the cost of energy resources for production needs in connection with the reduction in the production time of pastille masses. Differences also relate to fixed unit costs due to shorter process times. Calculations of other costs are made in relation to the cost of raw materials in accordance with products made according to the classical recipe The share of the cost of "Raw materials and materials" in the total cost is taken in the amount of $65.0 \%$, obtained focusing on similar industries. Under these conditions, "Other production and commercial costs" for the manufacture of control items is calculated:

- for marshmallow: $60.00 / 0.65 \cdot 0.35=32.3$ c.u.*;

- for pastilles: $54.24 / 0.65 \cdot 0.35=29.21$ c.u.*.

To determine other costs for the production of the developed pastilles, variable and fixed costs were adjusted, taking into account their relevance. So, the size of the reduction in variable costs due to a decrease in the cost of energy resources for the preparation of pastille mass is determined taking into account the share of the latter in the value of variable costs, the specific weight of the time for the corresponding operation in the total duration of the technological process and the rate of reduction of this time.

Consequently, the size of the reduction in variable costs in the manufacture of pastilles with stevia and elamin is: $0.12 \times 0.234 \times 0.88=0.025$ or $2.5 \%$; *

Reducing the duration of the technological process leads to an increase in output per unit of time, that is, an increase in labor productivity. In conditions of growth in the volume of production, the value of fixed costs is distributed between a large number of products and, accordingly, their size, which is related to the cost of a unit of production, decreases. Therefore, in the calculations of the cost of the developed products, the fixed costs for the rate of decrease in the time of the technological process were adjusted, namely for: pastilles -0.790 ; marshmallow -0.804 . Other costs are irrelevant and cannot be adjusted.

Taking into account the above, the cost price was calculated and the selling price of pastilles was formed are presented in Table 2.

In the course of the calculations, it was found that the current selling price of "Smakota" pastille and "Nasoloda" marshmallow is higher than the price of products made according to the classic recipe by 4.0 and $2.3 \%$, respectively. However, the results of calculating the cost of the "Exotica" marshmallow showed a decrease of $1.2 \%$, respectively, of the control sample.

The selling prices of pastilles have been calculated - this is the minimum level at which a manufacturer can sell its products. The company focuses on the level of profitability that has 
developed in this segment of the consumer market at the level of $15.0 \%$. This price level provides manufacturers of innovative products with competitive advantages in the consumer market, due to the high quality parameters of the developed products and prices that are in the market range.

Table 2

Calculations of the cost and wholesale prices of pastille products, c.u.

\begin{tabular}{cccccc}
\hline \multirow{2}{*}{ Indicator } & \multicolumn{4}{c}{ Pastilles } \\
\cline { 2 - 6 } & \multicolumn{4}{c}{ Pastille } & \multicolumn{2}{c}{ Marshmallow } \\
\cline { 2 - 5 } & «Vanil» (control) & «Exotica» & «Smakota» & «Vanil» (control) & «Nasoloda» \\
\hline Full cost & 83.45 & 82.49 & 86.78 & 92.33 & 94.43 \\
Profit (15.0 \%) & 12.52 & 12.37 & 13.02 & 13.85 & 14.17 \\
Cost at wholesale prices & 95.97 & 94.87 & 2993.9 & 99.80 & 108.6 \\
Wholesale price 1 kg & 0.96 & 0.95 & 1.00 & 1.06 & 1.09 \\
Value added tax & 0.192 & 0.19 & 1.00 & 0.21 & 0.217 \\
Sale price 1 kg & 1.15 & 1.14 & 1.20 & 1.27 & 1.30
\end{tabular}

Note: cost has not been adjusted to match today's price level

Improvement in quality characteristics, as a rule, leads to an increase in the volume of sales for goods in elastic demand. According to experts, the demand for pastilles is elastic depending on the quality, the coefficient of which is 1.08. Possible additional increase in the volume of sales of products due to improved quality is determined with a focus on the elasticity of demand from quality.

The demand for pastille products is also price elastic, that is, its decrease leads to an increase in demand, the corresponding coefficient of elasticity in this case is 2.8 . The decrease in prices is the source of the economic effect from the production of products, which can be traced in the production of Exotica pastilles. However, the obtained results of the highest quality control for the "Smakota" pastille and the "Nasoloda" marshmallow will lead to a slight drop in demand and, accordingly, sales proceeds, but this effect is offset by an increase in the consumer properties of the developed products. The overall growth in sales volume is calculated as the total influence of two factors - an increase in the quality of products and changes in their prices. An increase in the volume of activity leads to a reduction in unit fixed costs, noted above, and a corresponding increase in profitability. Calculations of the increase in profitability are presented in Table 3. On the basis of the growth rate of the volume of products sold, its increase in value terms and an additional increase in the mass of profit are determined, taking into account the level that has developed. The economic effect from the introduction of the developed pastilles is given in Table 4, calculations are made at prices excluding value added tax. The improved quality characteristics of pastilles according to the developed recipes are a source of social effect. A source of social effect in the case of purchasing Exotic pastilles is also a decrease in prices compared to products made according to traditional recipes. The calculation results are shown in Table 4.

Table 3

Calculations of the increase in the volume of sales and profitability of products

\begin{tabular}{|c|c|c|c|}
\hline Indicators & «Exotica» pastille & «Smakota» pastille & «Nasoloda» marshmallow \\
\hline Wholesale price of $1 \mathrm{~kg}$, c.u. & 0.95 & 1.0 & 1.09 \\
\hline The coefficient of elasticity of demand on quality & 1.08 & 1.08 & 1.08 \\
\hline Price elasticity of demand & 2.80 & 2.8 & 2.8 \\
\hline Quality ratio & 1.35 & 1.49 & 1.18 \\
\hline $\begin{array}{l}\text { Increase in the volume of sales of products due to quality } \\
\text { improvement, } \%\end{array}$ & 37.8 & 52.9 & 19.8 \\
\hline Change in sales volume due to price changes, $\%$ & +3.3 & -11.2 & -6.4 \\
\hline Total increase in sales volume, $\%$ & 41.1 & 41.7 & 13.4 \\
\hline The share of fixed costs in the price, $\%$ & 13.38 & 13.05 & 13.15 \\
\hline $\begin{array}{l}\text { Increase in profitability due to the level of conditionally } \\
\text { fixed costs. } \%\end{array}$ & 3.9 & 3.84 & 1.56 \\
\hline
\end{tabular}

Note: cost has not been adjusted to match today's price level 
Table 4

The economic effect of the introduction of pastilles made of stevia and elamin (per $100 \mathrm{~kg}$ of finished product)

\begin{tabular}{ccccc}
\hline No. & Types of economic effect & «Exotica» pastille & «Smakota» pastille & «Nasoloda» marshmallow \\
\hline 1 & Growth in the volume of products sold, c. u. & 41.0 & 39.6 & 14.6 \\
2 & Increase in the mass of profits, c. u. & 5.3 & 5.14 & 1.89 \\
3 & Increase in profitability, \% & 3.9 & 3.8 & 1.6
\end{tabular}

Note: cost has not been adjusted to match today's price level

\section{Discussion}

Thus, economic calculations confirm the effectiveness of the introduction of pastilles with stevia and elamin into production. The relatively low price and improved quality compared to analogs, enhance the value of the developed products for consumers, providing an opportunity to obtain an economic effect in the field of production from an increase in sales, profits and increased profitability. The socio-economic effect in the sphere of consumption consists in the ability to purchase products with increased consumer properties at calculated prices and to obtain relative savings (Table 5)

Table 5

The social effect of the introduction of pastilles with enhanced consumer properties

\begin{tabular}{ccccc}
\hline No. & Types of effect & «Exotica» pastille & «Smakota» pastille & «Nasoloda» marshmallow \\
\hline 1 & $\begin{array}{c}\text { Relative gain for consumers due to quality } \\
\text { improvement, \% }\end{array}$ & 26.8 & 30.2 & 13.3 \\
2 & Absolute savings (per 100 kg of product), c.u. & 1.33 & - & -
\end{tabular}

It was calculated and noted that the integral quality indicator of the developed pastilles is higher than that of the products made according to the corresponding classical recipes, and corresponds to the rating "very good". In particular, the integral assessment of the quality of the "Nasoloda" marshmallow exceeds the "Vanil" marshmallow, which was used as a control sample, by $10.2 \%$. The integral quality indicator of the "Exotica" and "Smakota" pastilles is 0.92 and 0.96 units, respectively, which is higher, respectively, than the "Vanil" pastilles (control) by 21.1 and $26.3 \%$. The obtained calculation data confirmed the feasibility of the development and implementation of the proposed recipe for pastilles, given that the economic effect was achieved only with the development of "Exotica" pastille, it is necessary to note the achievement of social effect. However, to confirm the calculations, the prospect determined the conduct of clinical trials.

\section{Conclusions}

According to the calculations of the cost price and the selling price of the developed pastilles, a decrease in the cost of the "Exotica" pastille was established for control, achieved by replacing the mass fraction of white sugar at the ASE and the introduction of elamin, by $1.2 \%$. products made according to the classical recipe by 4.0 and $2.3 \%$, which is the result of additional raw materials introduced into the products, increased the cost of raw materials, but is compensated by a decrease in the glycemic index, a change in the carbohydrate composition, enrichment with minerals, in particular iodine, vitamins, fiber, increased radioprotective properties, as evidenced by the integral quality indicator - "Nasoloda" surpasses control by $10.2 \%$, for the "Exotica" and "Smakota" pastilles it is 0.92 and 0.96 units, respectively, which exceeds by 21.1 and $26.3 \%$.

\section{References}

[1] Dukareva, G., Sokolovska, O. (2015). Technological parameters of the developed pastille products. Prohresyvni tekhnika ta tekhnolohii kharchovykh vyrobnytstv restorannoho hospodarstva i torhivli, 1 (21), 79-89.

[2] Sokolovska, O. O., Kryvosheieva, N. M. (2015). Marketynhovi doslidzhennia shchodo dotsilnosti rozrobky novykh vydiv pastylnykh vyrobiv. Ekonomika ta finansy. Viden, 242-248. 
[3] Sokolovska, O. O. (2016). Modeling pastille products recipe using unconventional raw materials in accordance with predetermined quality indicators. Technology Audit and Production Reserves, 3 (1 (29)), 21-27. doi: http://doi.org/10.15587/ 2312-8372.2016.72035

[4] Arsenieva, L. Yu., Dotsenko, Ya. F., Momot, O. O. (2005). Metodolohichni pidkhody do rozroblennia novykh vydiv khlibobulochnykh vyrobiv zi zbalansovanym khimichnym skladom. Kharchova promyslovist, 4, 5-8.

[5] Deinychenko, H. V., Kolisnychenko, T. O. (2005). Osnovni napriamky vykorystannia boroshnianykh formovanykh vyrobiv z yodvmishchuiuchymy dobavkamy $\mathrm{v}$ tekhnolohiiakh kulinarnykh produktsii. Obladnannia ta tekhnolohii kharchovykh vyrobnytstv. 12, 138-143.

[6] Korzun, V. N. (2011). Novi metody u profilaktytsi ta likuvanni yododefitsytnykh zakhvoriuvan u ditei. Aktualni pytannia pediatrii, akusherstva ta hinekolohii, 2, 128-130.

[7] Peresichnyi, M. I., Kravchenko, M. F., Karpenko, P. O., Karpachov, V. V. (2004). Pidsolodzhuvalni rechovyny u kharchuvanni liudyny. Kyiv: KNTEU, 446.

[8] Rudavska, H. B., Shapovalova, N. P., Rudavska, M. V., Zhukevych, O. V. (2012). New products for school food of the iodine deficiency biogeochemical provinces. 18th IGWT Symposium Technology and Innovation for a Sustainable Future: a Commodity Science Perspective. Rome, 487-499.

[9] Masuda, T., Yamashita, D., Maekawa, T., Sone, Y., Yamaguchi, H., Takeda, Y., Yamana, T. (2006). Identification of Antioxidative Compounds from Stevia (Stevia rebaudiana). Nippon Shokuhin Kagaku Kogaku Kaishi, 53 (12), 597-602. doi: http:// doi.org/10.3136/nskkk.53.597

[10] Rojas, E., Bermúdez, V., Motlaghzadeh, Y., Mathew, J., Fidilio, E., Faria, J. et. al. (2018). Stevia rebaudiana Bertoni and Its Effects in Human Disease: Emphasizing Its Role in Inflammation, Atherosclerosis and Metabolic Syndrome. Current Nutrition Reports, 7 (3), 161-170. doi: http://doi.org/10.1007/s13668-018-0228-z 